University of Nebraska - Lincoln

DigitalCommons@University of Nebraska - Lincoln

Mechanical \& Materials Engineering Faculty

Publications

Mechanical \& Materials Engineering

Department of

2016

How a Single Cell Sense its Mechanical Environment?

Shengmao Lin

University of Nebraska-Lincoln, linshengmao@gmail.com

Linxia Gu

University of Nebraska-Lincoln, gul@fit.edu

Follow this and additional works at: https://digitalcommons.unl.edu/mechengfacpub

Lin, Shengmao and Gu, Linxia, "How a Single Cell Sense its Mechanical Environment?" (2016). Mechanical \& Materials Engineering Faculty Publications. 157.

https://digitalcommons.unl.edu/mechengfacpub/157

This Article is brought to you for free and open access by the Mechanical \& Materials Engineering, Department of at DigitalCommons@University of Nebraska - Lincoln. It has been accepted for inclusion in Mechanical \& Materials Engineering Faculty Publications by an authorized administrator of DigitalCommons@University of Nebraska Lincoln. 


\section{How a Single Cell Sense its Mechanical Environment?}

\section{Shengmao $\operatorname{Lin}^{1}$ and Linxia Gu ${ }^{1,2 *}$}

${ }^{1}$ Department of Mechanical and Materials Engineering, University of Nebraska-Lincoln, Lincoln, NE, 68588-0656, USA

${ }^{2}$ Nebraska Center for Materials and Nanoscience, Lincoln, NE 68588-0656, USA

The extracellular matrix (ECM) is essential for regulating cell behavior and tissue function [1]. Local ECM structure and mechanics are increasingly recognized as important mechanical effectors of cell responses and tissue regeneration [2]. This is illustrated by the fact that either the rigidity of ECM [3] or local tension regulate cellular mechanotransduction pathways, and their dysregulation results in many different types of diseases [4,5]. It was speculated that cell contractions, generated by the cross-bridging interaction of actin and myosin II motors, maintain a tensional homeostasis in response to mechanical disturbance. The question is what is exactly the tensional homeostasis, if any?

The first detailed characterization of a tensional homeostasis in cells was conducted by Brown et al. [6]. They observed an equilibrium force in the collagen gel containing living dermal fibroblast cells following different mechanical disturbance. This equilibrium force, which is typically around 40-60 dynes/million cells, was considered as the tensional homeostasis. Utilizing scanning probe microscopy, Mizutani et al. found out that the stiffness of fibroblast changed rapidly in response to external loadings; however the long term stiffness of cells does not change [7]. A newer technique, traction force microscopy (TFM) allows researchers to better visualize single cell induced mechanical forces on the substrate [8]. In general, cells are seeded on substrate with embedded microbeads. The cell contraction caused movement of microbeads, i.e., displacement field, are tracked and converted to traction stress field, which is an indirect measure of the cellular contraction forces. The regulation of force transmission has attracted a lot of efforts using TFM.

The traction force of a single cell was found to be correlated with cell spread area, cell shape, cell stiffness and substrate stiffness [911]. However the role of substrate stiffness on cell shape and stiffness depends on cell types. For example, fibroblasts and endothelial cells increase their spread area abruptly around the substrate stiffness of $3 \mathrm{kPa}$, while neutrophils are not sensitive to the substrate stiffness at all [12]. It was also observed that cell stiffness increased when cultured on stiffer substrate [13]. This is due that cells on a stiff substrate reorganize actin cytoskeleton into bundles or stress fibers, facilitating a larger tensile stresses generated by myosin motor [14]. Moreover, the cellcell contacts led to the neglected role of substrate stiffness on the cell shape and cytoskeletal stiffening [12]. A lot of efforts focus on isolating the role of individual mechanical parameters including cell shape, cell stiffness; cell spread area, focal adhesion density, and substrate stiffness. Tee et al. delineated the interaction among cell shape, cell stiffness and substrate stiffness [11]. They observed that the stiffness of cells, cultured on a soft substrate, is more sensitive to the substrate stiffness. For a stiffer substrate, the cell stiffness is more sensitive to cell shape, related to the density of focal adhesions. However the density of focal adhesions has a positive correlation with the substrate stiffness [15]. This implied the challenges to decouple the role of cell shape and substrate stiffness.

A microcontact printing technique, specifically micropost arrays, was developed to address this decoupling issue. Han et al. observed that traction forces were more sensitive to focal adhesions [16]. However, this contradicts with the work by Califano et al. [9]. They found that the focal adhesion density was not a significant predictor of traction force. Further investigation and analysis are needed to interpolate these contradictory observations from various experimental protocols.

Virtual testing using numerical or theoretical model has been an efficient tool for integrating various experimental data to understand the cell-ECM interactions and its resulted traction forces. Zielinski et al. has simulated the two dimensional and three dimensional cell-ECM interactions to quantify the sensitivity of traction force to biomechanical parameters, such as cell stiffness, focal adhesion density, cell aspect ratio and contractility [17]. The cell stiffness and focal adhesion density were identified as two major parameters affecting the traction forces. Oakes et al. has proposed a physical model for adherent cells considering uniform contractility combined with a uniform boundary line tension [18]. They found out that the cell shape regulated the traction force distributions in order to maintain a constant strain energy density of each cell. Our group also developed a numerical model to capture the cell-ECM interactions for identifying the tensional homeostasis of cells. The peak displacements of micro beads were observed in locations with large curvatures as shown in Figure 1. We have shown that cells altered their shapes and stiffness to exert various level of traction forces in response to different substrate stiffness. However, the cellular strain as well as its strain energy density was kept constant regardless of changes in substrate stiffness, cell shape and cell stiffness. This indicated that cellular strain could serve as tensional homeostasis of cells cultured on different mechanical environment. Our results suggested that measurement of contractility might be useful for monitoring cell mechanosensing as well as dynamic remodeling of ECM.

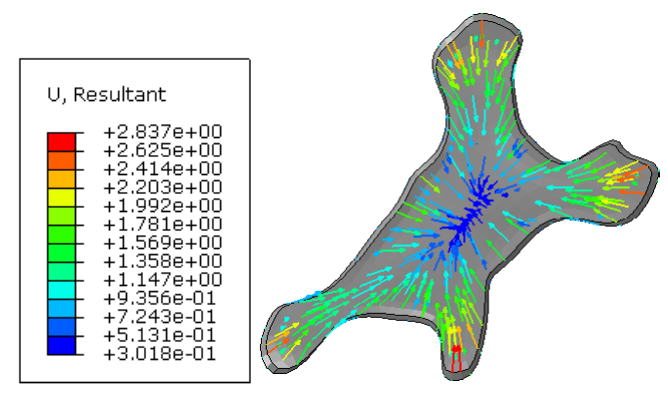

Figure 1: Simulated traction displacement map (unit: $\mu \mathrm{m}$ ) of bovine aortic endothelial cell cultured on a substrate stiffness of $1 \mathrm{kPa}$.

*Corresponding author: Linxia Gu, Department of Mechanical and Materials Engineering, University of Nebraska-Lincoln, 1400 R St, Lincoln, NE 68588-0656, USA, Tel: 4024727680; E-mail: Igu@unl.edu

Received March 03, 2016; Accepted March 08, 2016; Published March 18, 2016

Citation: Lin S, Gu LX (2016) How a Single Cell Sense its Mechanical Environment? J Biosens Bioelectron 7: 201. doi:10.4172/2155-6210.1000201

Copyright: (c) 2016 Lin S, et al. This is an open-access article distributed under the terms of the Creative Commons Attribution License, which permits unrestricted use, distribution, and reproduction in any medium, provided the original author and source are credited. 
In summary, various devices and techniques were developed to inspect the mechanism by which cells sense the mechanical environment. They will continue to play essential roles in understanding many biological processes, such as cancer cell migration, morphogenesis, and differentiation.

\section{References}

1. Discher DE, Janmey P, Wang YI (2005) Tissue cells feel and respond to the stiffness of their substrate. Science 310: 1139-1143.

2. Yu H, Mouw JK, Weaver VM (2011) Forcing form and function: biomechanical regulation of tumor evolution. Trends in cell biology 21: 47-56.

3. Hadjipanayi E, Mudera V, Brown RA (2009) Guiding cell migration in 3D a collagen matrix with graded directional stiffness. Cell motility and the cytoskeleton $66: 121-128$

4. Zhao S, Stamm A, Lee JS, Gruverman A, Lim JY, et al (2015) Elasticity of Differentiated and Undifferentiated Human Neuroblastoma Cells Studied by Atomic Force Microscopy. Journal of Mechanics in Medicine and Biology 15: 5.

5. Rittweger J, Simunic B, Bilancio G, Santo NGD, Cirillo M, et al. (2009) Bone loss in the lower leg during 35 days of bed rest is predominantly from the cortical compartment. Bone 44: 612-618.

6. Brown R, Prajapati R, McGrouther D, Yannas I, Eastwood M (1998) Tensiona homeostasis in dermal fibroblasts: mechanical responses to mechanical loading in three-dimensional substrates. Journal of cellular physiology 175 : 323-332.

7. Mizutani T, Haga H, Kawabata K (2004) Cellular stiffness response to external deformation: tensional homeostasis in a single fibroblast. Cell motility and the cytoskeleton 59: 242-248.

8. Munevar S, Wang YI, Dembo M (2001) Traction force microscopy of migrating normal and H-ras transformed 3T3 fibroblasts. Biophysical journal 80: 17441757.
9. Califano JP, Reinhart-King CA (2010) Substrate stiffness and cell area predict cellular traction stresses in single cells and cells in contact. Cellular and molecular bioengineering 3: 68-75.

10. Rape AD, Guo WH, Wang YI (2011) The regulation of traction force in relation to cell shape and focal adhesions. Biomaterials 32: 2043-2051.

11. Tee SY, Fu J, Chen CS, Janmey PA (2011) Cell shape and substrate rigidity both regulate cell stiffness. Biophysical journal 100: L25-L27.

12. Yeung T, Georges PC, Flanagan LA, Marg B, Ortiz M, et al. (2005) Effects of substrate stiffness on cell morphology, cytoskeletal structure, and adhesion. Cell motility and the cytoskeleton 60: 24-34.

13. Solon J, Levental I, Sengupta K, Georges PC, Janmey PA (2007) Fibroblast adaptation and stiffness matching to soft elastic substrates. Biophysical journal 93: 4453-4461.

14. Wang N, Tolic-Norrelykke IM, Chen J, Mijailovich SM, Butler JP (2002) Cell prestress I Stiffness and prestress are closely associated in adherent contractile cells. American Journal of Physiology-Cell Physiology 282: 606-616.

15. Prager-Khoutorsky M, Lichtenstein A, Krishnan R, Rajendran K, Mayo A (2011) Fibroblast polarization is a matrix-rigidity-dependent process controlled by focal adhesion mechano-sensing. Nature cell biology 13: 1457-1465.

16. Han SJ, Bielawski KS, Ting LH, Rodriguez ML, Sniadecki NJ (2012) Decoupling substrate stiffness, spread area, and micropost density: a close spatial relationship between traction forces and focal adhesions. Biophysical journal 103: 640-648.

17. Zielinski R, Mihai C, Kniss D, Ghadiali SN (2013) Finite element analysis of traction force microscopy: influence of cell mechanics, adhesion, and morphology. Journal of biomechanical engineering 135: 71009.

18. Oakes PW, Banerjee S, Marchetti MC, Gardel ML (2014) Geometry regulates traction stresses in adherent cells. Biophysical journal 107: 825-833.
Citation: Lin S, Gu LX (2016) How a Single Cell Sense its Mechanical Environment? J Biosens Bioelectron 7: 201. doi:10.4172/2155-6210.1000201
OMICS International: Publication Benefits \& Features

Unique features:

- Increased global visibility of articles through worldwide distribution and indexing

Showcasing recent research output in a timely and updated manner

Special issues on the current trends of scientific research

Special features:

$700+$ Open Access Journals

$50,000+$ Editorial team

Rapid review process

Quality and quick editorial, review and publication processing

Indexing at major indexing services

Sharing Option: Social Networking Enabled

Authors, Reviewers and Editors rewarded with online Scientific Credits

Better discount for your subsequent articles

Submit your manuscript at: http://www.omicsonline.org/submission 